\title{
Breeding of Four-way Cross Rats among Inbred Strains and their Characteristics
}

\author{
Hisao TANASE, Naochika MATSUNUMA, and Yoshio SUZUKI \\ Laboratory Animal Science and Toxicology Laboratories, Sankyo Co., Ltd. \\ 717 Horikoshi, Fukuroi-shi, Shizuoka-ken 437, Japan
}

(Received for publication: March 28, 1983)

\begin{abstract}
The present study is an attempt to utilize hybrids among several inbred strains of rats as useful animals for the studies of effectiveness and toxicology on drugs. Four-way crosses were made among the LEW, WM, F344 and DRY strains of rats, and their characteristics were examined. From the breeding data of diallel crosses among these four strains and reciprocal crosses among their $F_{1}$ hybrids, the mating type indicating the highest reproductivity was (LEW $\times \mathrm{WM}$ ) $F_{1} \times(F 344 \times D R Y) F_{1}$. These four-way crosses were designated as LWFD. The reproductivity of this mating type was exceedingly higher than those of four strains. In order to examine the susceptibility to thiamine hydrochloride, the acute toxicity test was practiced in inbred strains, $F_{1}$ hybrids and four-way crosses. As a result, in spite of highly heterogeneous population, the LWFD did not show a peculiar response in comparison with four strains and their $F_{1}$ hybrids. Furthermore, hematological and clinico-biochemical values of the LWFD did not show a large variability as presumed. From these results, it is suggested that hybrids such as four-way crosses among inbred strains can be used as useful animals for the studies of effectiveness and toxicology on drugs.
\end{abstract}

\section{4 元交雑ラットの検定用動物としての利用}

棚瀬 久雄・松沼尚史・鈴木善雄

三共株式会社安全性研究所

実験動物はその遺伝的統御方法により近交系, ミュー タント系，クローズドコロニー交雑群に分類され[13], 特に検定用動物にはクローズドコロニーと一部の近交系 が用いられている。実験動物としての価値は遺伝子組成 の整一性または垣久性, 特性. 大量生産などの観点から 論じられなければならないが，検定用動物は特に集団の 遺伝的構造の恒久性とその集団に遺伝的分化がないとい 共通性を満足できる形で大量生産が可能なことであ る [9]。クローズドコロニーは継代中に遺伝的に変化す る可能性があり, 形質や反応の恒久性に必ずしも問題が
ないわけではない[14,15,19]。一方，近交系については 一般的に繁殖力が低いので大量生産の面で難点がある。 さらに薬物などに対する感受性には近交系間で大きな差 が見られることもあり $[5,11,12]$ ，薬物の有効性や毒性 試験の場合には 1 系統のみの結果からその種全体の反忘 性を推察することは困難である。しかしながら特に毒性 試験のような場合にはいくつかの系統を用いて試験を行 ならのは実際的に困難である。

これに対して近年使用されるようになってきた近交系 間の $F_{1}$ 交雑群は有利な点を有している。その一つはへ 
テロシス $[1,16]$ 。である。すなわち, 繁殖力に優れ，強 健で, 飼育管理に多少の変化があっても近交系のよ5に 影響を受けにくいといらことである。さらに $\mathrm{F}_{1}$ 交雑群 は近交系に見られなかった特性を有するものが多く[8], 整一性と特性を有することから研究用動物としての価值 も高い。このような観点から近交系間の $\mathrm{F}_{1}$ 交雑群が加 齢・老化を含む色々な研究分野で使用されるようになっ てきた $[3,4]$ 。そこで，この考方方をさらに進めて起源 の異なるいくつかの近交系間の $\mathrm{F}_{1}$ 交雑群を検定用動物 として利用できないであろらかと考えた。

この実験は新しい検定用動物の育成を目的にして 4 系 統ラットの交雑群, すなわち 4 元交雑群について繁殖効 率を調べ，薬物に対する感受性ならびに血液・臨床生化 学的検查を行ない, 検定用動物としての適性を検討した ものである。

\section{材料およひ方法}

\section{1. 実験動物}

実験には三共安全性研究所のバリアシステムの環境下 で系統維持されている LEW, W M, F344 および DRY の 4 系統ラットを用いた。LEW は Pennsylvania 大 学より Simonsen Laboratories Inc. を経由して1973 年に $\mathrm{F}_{39}$ で当研究所に導入されたもので, 実験には $\mathrm{F}_{50-}$ ${ }_{53}$ のものを使用した。WMは国立遺伝学研究所より 1972 年に $\mathrm{F}_{62}$ で導入され， $\mathrm{F}_{71-76}$ のものを用いた。F344 は 米国の Charles River Inc. より1968年に導入したクロ ーズドコロニーで, その後は兄妹交配で維持され, 実験 には $\mathrm{F}_{16-20}$ のものを使用した。DRY は日本ラット(株) でクローズドコロニーとして生産されている Donryuを 1971年に購入し, 近交系として育成途上にある $\mathrm{F}_{14-18}$ の ものを使用した。

動物は温度 $24 \pm 2^{\circ} \mathrm{C}$, 湿度 $55 \pm 10 \%$ に統御されたバリ 了内で飼育され， $3 \times 10^{6} \mathrm{R}$ の ${ }^{60} \mathrm{co}$ 線で滅菌したオリエ ンタル醅母工業(株)生産の $\mathrm{CMF}$ 固型飼料と $10 \mathrm{ppm} ク$ ロール水を与えた。

\section{2. 交雑実験}

最初に 4 元交雑群生産の種親となる $F_{1}$ を作出するた めの系統間交配の組合せを検討した。 4 系統間ですべて の組合せの交配 (diallel cross) を行ない，繁殖成績を 調べた。各系統ともに 13-16週㱓の雌を 61-64匹，10-20 週齢の雄を 13-16 匹用いて 1 週間同居させた後に個別飼 育し, 出産・哺育させ, 4 週で離乳した。これらの繁殖 成績をもとにして，交配から離乳までの期間に，交配に
使用した雌 1 匹が 1 週間あたりに生産しは仔の数，すな わち，〔離乳仔数/交配雌数/交配から離乳までの期間 (8 週間)]，を繁殖効率として比較した。

次にこの diallel cross の実駼結果より比較的繁殖効 率の優れた系統の組合せより得られた $\mathrm{F}_{1}$ 交雑群を 8 種 類選び出し，4つの組合せによる正逆交配を行ない，4 元交雑群を作出した。各 $\mathrm{F}_{1}$ 組合せともに11〜18週龄の 雌雄をそれぞれ10匹ずつ用いて上記の $F_{1}$ 作出の場合と 同様に繁殖効率を調べた。なお，この実験では実際の生 産といらことを考虑に入れて, 出産日に哺育仔数を12匹 に調整することにした。しかしながら，出産母体数が少 ないので哺育仔をすべて12匹に調整できず，10１2匹に なった。

以上の交雑実験結果より 4 元交雑群作出に関して最も 繁殖効率の優れた $F_{1}$ の組合せを選び出し， 6 週齢の $F_{1}$ 雌と 9 週齢の $F_{1}$ 雄を24匹ずつ用いて同様に10産までの 経産実験を行なった。

3. 特性チェック

使用した LEW，WM，F344，DRY の 4 系統とこれ らの交雑によって得られた $F_{1}$ ならびに 4 元交雑群につ いて 6 週齢より18週齢までの体重を測定した。

5 週路の 4 系統 および 4 種類の $F_{1}$ ならびに 4 元交雑 群の䧳雄をそれぞれ32匹ずつ用いてビタミン $\mathrm{B}_{1}$ 塩酸塩の $3 \%$ 等張液を尾静脈内に 投与して急性毒性試験を行な い, 死亡率から Litchfield-Wilcoxon 法 [10]により $\mathrm{LD}_{50}$ 值を算出した。

さらに10週齢の各系統， $\mathrm{F}_{1}$ ならびに 4 元交雑群の雌雄 をとれぞれ10匹ずつ用いてエーテル軽麻酔下で腹部大動 脈より採血を行ない，赤血球数 (RBC), へモグロビン 量 $(\mathrm{Hb}), ヘ$ 、トクリット值 $(\mathrm{Ht})$, 赤血球平均恒数 $(\mathrm{MCH}, \mathrm{MCV}, \mathrm{MCHC})$, 血小板数 ( Th), 白血球数 (WBC) を求めた。をた血液の一部は血清を分離し, 日 立 726 型自動分析機により, 総ビリルビン量 (T. bil), 総コレステロール量 (T. chol), 総蛋白量 (T. prot), アルブミン量 (Alb), 尿素窒素量 (BUN), GOT, GPT, アルカリ性フォスファターゼ活性（Alp）を測定した。

\section{成 嚗}

4 系統間の diallel cross の繁殖成績を Table 1 に 示す。雌 1 匹当りの 1 週間の生産数を指標にすると最も 繁殖効率の高い組合せは $\mathrm{DRY} \times \mathrm{WM}$ ，次いで F $344 \times$ $\mathrm{WM} ， \mathrm{DRY} \times \mathrm{F} 344$ の順であった。逆に繁殖効率の低 い組合せは $\mathrm{WM} \times \mathrm{DRY}, \mathrm{F} 344 \times \mathrm{LEW}, \mathrm{LEW} \times \mathrm{F} 344$ 
Table 1. Breeding data in sixteen mating types among four inbred strains of rats

\begin{tabular}{cccccc}
\hline $\begin{array}{c}\text { Mating type } \\
\text { Female }\end{array}$ Male & $\begin{array}{c}\text { Fertile dam } \\
(\%)\end{array}$ & $\begin{array}{c}\text { Number of newborns } \\
\text { (Mean } \pm \text { S. E. M.) }\end{array}$ & $\begin{array}{c}\text { Nursing } \\
\text { rate } \%)\end{array}$ & Reproductivity* \\
\hline L EW & L EW & $14 / 16(87.5)$ & $142(10.1 \pm 0.6)$ & 94.4 & 1.05 \\
& WM & $14 / 16(87.5)$ & $147(10.5 \pm 1.0)$ & 98.6 & 1.13 \\
& F 344 & $10 / 15(66.7)$ & $115(11.5 \pm 0.7)$ & 100.0 & 0.96 \\
& D R Y & $13 / 16(81.3)$ & $149(11.5 \pm 0.5)$ & 99.3 & 1.16 \\
WM & WM & $12 / 13(92.3)$ & $113(9.4 \pm 0.5)$ & 99.1 & 1.08 \\
& F 344 & $13 / 16(81.3)$ & $138(10.6 \pm 0.6)$ & 93.5 & 1.01 \\
& D R Y & $10 / 16(62.5)$ & $90(9.0 \pm 1.0)$ & 98.9 & 0.70 \\
& L EW & $13 / 16(81.3)$ & $139(10.7 \pm 0.7)$ & 100.0 & 1.09 \\
F344 & F 344 & $14 / 16(87.5)$ & $133(9.5 \pm 0.6)$ & 100.0 & 1.04 \\
& D R Y & $13 / 16(81.3)$ & $129(9.9 \pm 0.4)$ & 100.0 & 1.01 \\
& L EW & $11 / 16(68.8)$ & $122(11.1 \pm 0.3)$ & 99.2 & 0.95 \\
& WM & $16 / 16(100.0)$ & $176(11.0 \pm 0.5)$ & 100.0 & 1.38 \\
D RY & D R Y & $15 / 16(93.8)$ & $158(10.5 \pm 0.8)$ & 94.3 & 1.16 \\
& L EW & $12 / 16(75.0)$ & $147(12.3 \pm 0.8)$ & 99.3 & 1.14 \\
& WM & $15 / 16(93.8)$ & $182(12.1 \pm 0.4)$ & 98.4 & 1.40 \\
& F 344 & $13 / 16(81.3)$ & $167(12.8 \pm 0.6)$ & 99.4 & 1.30 \\
\hline
\end{tabular}

* The average number of offspring produced by a female parent for one week.

Table 2. Breeding data in eight mating types among reciprocal $F_{1}$ hybrids

\begin{tabular}{ccccc}
\hline $\begin{array}{c}\text { Mating type } \\
\text { Female } \times \text { Male }\end{array}$ & $\begin{array}{c}\text { Fertile dam } \\
(\%)\end{array}$ & $\begin{array}{c}\text { Number of newborns } \\
(\text { Mean } \pm \text { S. E. M. })\end{array}$ & $\begin{array}{c}\text { Nursing } \\
\text { rate }(\%)\end{array}$ & Reproductivity* \\
\hline $\mathrm{LWF}_{1} \times \mathrm{FDF}_{1}$ & $10 / 10(100.0)$ & $139(13.9 \pm 0.4)$ & 100.0 & 1.50 \\
$\mathrm{FDF}_{1} \times \mathrm{LWF}_{1}$ & $10 / 10(100.0)$ & $124(12.4 \pm 0.7)$ & 100.0 & 1.45 \\
$\mathrm{LDF}_{1} \times \mathrm{FWF}_{1}$ & $10 / 10(100.0)$ & $141(14.1 \pm 0.6)$ & 98.3 & 1.45 \\
$\mathrm{FWF}_{1} \times \mathrm{LDF}_{1}$ & $10 / 10(100.0)$ & $121(12.1 \pm 0.5)$ & 100.0 & 1.37 \\
$\mathrm{DLF}_{1} \times \mathrm{WFF}_{1}$ & $9 / 10(90.0)$ & $117(13.0 \pm 0.4)$ & 99.1 & 1.33 \\
$\mathrm{WFF}_{1} \times \mathrm{DLF}_{1}$ & $10 / 10(100.0)$ & $120(12.0 \pm 0.4)$ & 100.0 & 1.46 \\
$\mathrm{DFF}_{1} \times \mathrm{WLF}_{1}$ & $10 / 10(100.0)$ & $124(12.4 \pm 0.8)$ & 99.1 & 1.39 \\
$\mathrm{WLF}_{1} \times \mathrm{DFF}_{1}$ & $10 / 10(100.0)$ & $130(13.0 \pm 0.5)$ & 100.0 & 1.50 \\
\hline
\end{tabular}

* The average number of offspring produced by a female parent for one week.

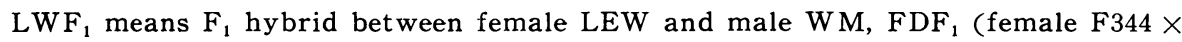
male DRY), and so on.

で，この原因は出産率の低いことに起因していた。な お，WM を雌にすると，効率が悪い上らであったが， これは産仔数が少ないことによるものであった。正逆交 配の差がはっきり見られる組合せもあるが，F344と LEW の正逆交配はともに繁殖効率が低いようであっ た。

4 系統の diallel cross の結果から比較的繁殖効彎の 優れた $\mathrm{LWF}_{1}$ (LEW ㅇ と WM $\delta$ との $\mathrm{F}_{1}$ 交雑群, 以下, 同様の表記を行なら), $\mathrm{FDF}_{1}, \mathrm{LDF}_{1}, \mathrm{FWF}_{1}$,
$\mathrm{DLF}_{1}, \mathrm{WFF}_{1}, \mathrm{DFF}_{1}, \mathrm{WLF}_{1}$ の 8 種類の $\mathrm{F}_{1}$ 交雑群を 選びだし，4組の正逆交配を行なった結果を Table 2 に示す。なお，最も繁殖効率の優れていた $\mathrm{DWF}_{1}$ を除 いた理由は、これを選びだした場合の交配相手が繁殖効 率の悪い $\mathrm{FLF}_{1}$ または $\mathrm{LFF}_{1}$ となるからである。その結 果, いずれの組合せに颃いても出産率, 産仔数, 離乳率 ともに高く，繁殖効率は非常に優れていた。最も優れた 組合せは $\mathrm{LWF}_{1} \times \mathrm{FDF}_{1}$ と $\mathrm{WLF}_{1} \times \mathrm{DFF}_{1}$ であった。 しかし前者の方の産仔数が多いことを考虑して，4 元交 
Table 3. Breeding data of the mating between female $\mathrm{LWF}_{1}$ and male $\mathrm{FDF}_{1}$

\begin{tabular}{|c|c|c|c|c|c|c|}
\hline \multirow{2}{*}{$\begin{array}{l}\text { Birth } \\
\text { order }\end{array}$} & \multirow{2}{*}{$\begin{array}{l}\text { Body weight of } \\
\text { mating dam (g) }\end{array}$} & \multirow{2}{*}{$\begin{array}{c}\text { Fertile dam } \\
(\%)\end{array}$} & \multirow[t]{2}{*}{ Litter size } & \multirow{2}{*}{$\begin{array}{l}\text { Nursing } \\
\text { rate }(\%)\end{array}$} & \multicolumn{2}{|c|}{$\begin{array}{l}\text { Body weight ofweanlings } \\
\text { at } 4 \text { weeks of age }(g)\end{array}$} \\
\hline & & & & & female & male \\
\hline $1 \mathrm{st}$ & $116.9 \pm 1.5$ & $24 / 24(100.0)$ & $11.8 \pm 0.5$ & 100.0 & $59.4 \pm 0.6$ & $65.2 \pm 0.7$ \\
\hline 2 nd & $206.3 \pm 2.0$ & $24 / 24(100.0)$ & $14.8 \pm 0.4$ & 99.7 & $53.6 \pm 0.4$ & $61.7 \pm 0.5$ \\
\hline $3 \mathrm{rd}$ & $227.8 \pm 2.0$ & $24 / 24(100.0)$ & $13.6 \pm 0.6$ & 99.7 & $64.4 \pm 0.5$ & $68.3 \pm 0.6$ \\
\hline 4 th & $254.6 \pm 1.5$ & $19 / 23(82.6)$ & $12.9 \pm 0.9$ & 99.6 & $60.9 \pm 0.6$ & $65.7 \pm 0.6$ \\
\hline $5 \mathrm{th}$ & $273.6 \pm 1.8$ & $23 / 24(95.8)$ & $13.7 \pm 0.6$ & 99.3 & $62.0 \pm 0.6$ & $66.6 \pm 0.7$ \\
\hline $6 \mathrm{th}$ & $277.9 \pm 2.0$ & $22 / 23(95.7)$ & $13.2 \pm 0.5$ & 98.2 & $62.5 \pm 0.5$ & $66.4 \pm 0.7$ \\
\hline 7 th & $288 \cdot 7 \pm 2 \cdot 6$ & $22 / 23(95.7)$ & $12.0 \pm 0.5$ & 100.0 & $58.2 \pm 0.7$ & $60.9 \pm 0.6$ \\
\hline 8 th & $290.8 \pm 3.3$ & $21 / 23(91.3)$ & $10.1 \pm 0.2$ & 100.0 & $68.2 \pm 0.7$ & $75.3 \pm 0.9$ \\
\hline 9 th & $290.0 \pm 4.6$ & $13 / 21(61.9)$ & $8.8 \pm 0.9$ & 100.0 & $65.9 \pm 1.4$ & $68.5 \pm 1.6$ \\
\hline 10 th & $291.4 \pm 6.7$ & $7 / 21(33.3)$ & $4.9 \pm 1.5$ & 100.0 & $67.7 \pm 2.7$ & $75.3 \pm 1.7$ \\
\hline
\end{tabular}

The data are expressed as mean \pm S. E. M.

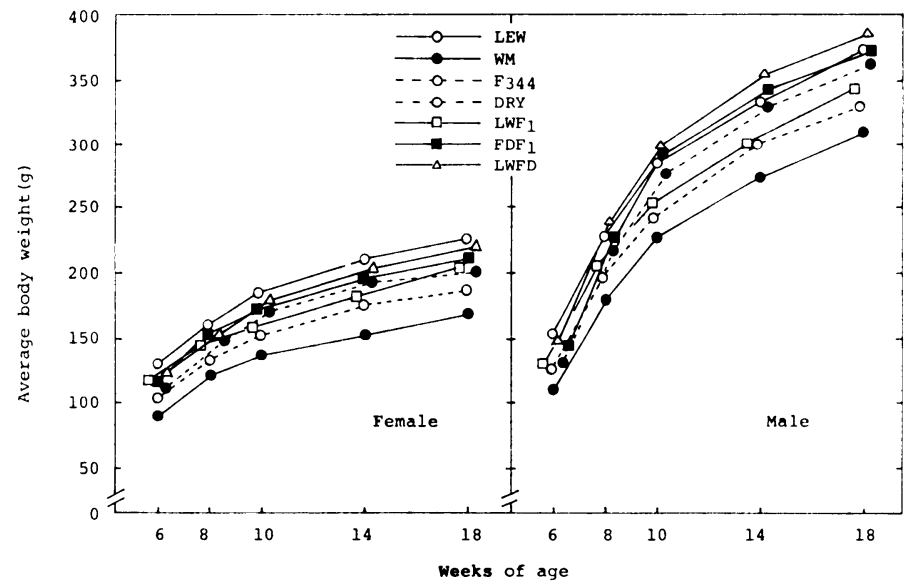

Fig. 1. Body weight changes of female and male rats in each genotype.

雑の組合せを $\mathrm{LWF}_{1} \times \mathrm{FDF}_{1}$ と決定した。これから生産 された 4 元交雑群を以下 LWFD と表記する。

$\mathrm{LWF}_{1}$ と $\mathrm{FDF}_{1}$ の交配の組合せに和ける10産までの 経産実験の結果を Table 3 に示す。1〜3産までの出 産率は100\%であったが，その後はやや減少を示し，4〜 8 産までは83〜91\%であった。しかしながら，9 産以後 は急激に減少を示した。平均産仔数は 1 産から 2 産にか けて増加を示し，2 産で14. 8匹と最も多くなり，3〜7 産までは12.0〜13.7匹であった。しかしながら，その後 は著明に減少を示した。離乳率は10産まで $98 \%$ 以上と安 定した結果が得られた。生産された LWFD の 4 週龄に 拈ける平均体重は, 雌で 53.6〜62.8 g, 雄では 60.9〜 $75.3 \mathrm{~g}$ と産次間でやや変動が見られた。
4 系統と $\mathrm{LWF}_{1}$ および $\mathrm{FDF}_{1}$ ならびに LWFD の 雌雄の 6 ～18週齢の平均体重の増加を Fig. 1. に示す。 雌では LEW が最も大きく, 次いで LWFD, FDF 1 , $\mathrm{DRY}, \mathrm{LWF}_{1}$ の順で, WM は最も小さかった。これ に対して雄では LWFD が最も大きく，その後の順序は ほぼ䊒と同様であった。なお，図には示さなかったが， LWFD の30週齢の体重は雌で $236 \pm 4.1 \mathrm{~g}$, 雄で $421 \pm$

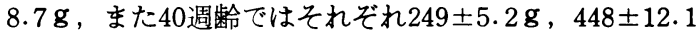
gであった。

4 系統と 4 種類の $\mathrm{F}_{1}$ および 4 元交雑群の 5 週齡に括 ける平均体重とビタミン $\mathrm{B}_{1}$ 塩酸塩に対する急性毒性の $\mathrm{LD}_{50}$ 值と $95 \%$ 信頼区間を Table 4 に示す。 4 系統を比 較すると雌雄ともに DRY が最も高い值を示し, 最も低 
Table 4. Susceptibility to thiamine hydrochloride in each genotype of rats

\begin{tabular}{|c|c|c|c|c|c|}
\hline \multirow{2}{*}{ Classification } & \multirow[b]{2}{*}{ Symbol } & \multicolumn{2}{|c|}{ Female } & \multicolumn{2}{|r|}{ Male } \\
\hline & & $\begin{array}{c}\text { Body weight } \\
\text { (g) }\end{array}$ & $\mathrm{LD}_{50}(\mathrm{mg} / \mathrm{kg})$ & $\begin{array}{c}\text { Body weight } \\
(\mathrm{g})\end{array}$ & $\mathrm{LD}_{50}(\mathrm{mg} / \mathrm{kg})$ \\
\hline \multirow[t]{4}{*}{ Inbred } & LEW & $97.0 \pm 0.6$ & $116.9(110.4-123.8)$ & $114.4 \pm 0.9$ & $121.1(112.8-130.1)$ \\
\hline & W M & $78.5 \pm 1.2$ & $134.9(126.2-144.2)$ & $90.6 \pm 1.4$ & $127.6(118.8-137.0)$ \\
\hline & F 344 & $79.8 \pm 0.9$ & $141.9(130.7-154.1)$ & $90.6 \pm 1.3$ & $118.9(112.3-125.9)$ \\
\hline & DRY & $80.2 \pm 0.8$ & $151.7(141.2-162.9)$ & $94.3 \pm 0.9$ & $141.9(130.5-154.2)$ \\
\hline \multirow[t]{4}{*}{$F_{1}$ hybrids } & $\mathrm{LWF}_{1}$ & $92.7 \pm 1.3$ & $143.5(132.4-155.6)$ & $107.3 \pm 1.3$ & $134.0(125.0-143.6)$ \\
\hline & $\mathrm{FDF}_{1}$ & $100.4 \pm 1.3$ & $122.8(114.6-131.6)$ & $110.5 \pm 2.3$ & $125.6(116.9-134.9)$ \\
\hline & $\mathrm{LDF}_{1}$ & $96.9 \pm 0.9$ & $132.7(122.6-143.6)$ & $110.2 \pm 1.3$ & $125.0(116.4-134.3)$ \\
\hline & $\mathrm{FWF}_{1}$ & $86.6 \pm 0.5$ & $129.4(122.3-136.9)$ & $95.2 \pm 0.7$ & $121.1(114.2-128.4)$ \\
\hline \multirow[t]{4}{*}{ 4-way cross } & LWFD & $89.5 \pm 0.7$ & $146.6(134.4-159.9)$ & $99.0 \pm 1.1$ & $135.5(124.8-147.2)$ \\
\hline & FDLW & $101.8 \pm 0.8$ & $121.1(112.8-130.1)$ & $114 \cdot 4 \pm 1.1$ & $123.3(113.3-134.2)$ \\
\hline & LDFW & $96.6 \pm 1.2$ & $142.2(131.1-153.9)$ & $108.8 \pm 1.0$ & $141.9(131.8-152.8)$ \\
\hline & FWLD & $89.8 \pm 0.9$ & $127.9(119.3-137.1)$ & $102.6 \pm 1.2$ & $117.2(109.6-125.3)$ \\
\hline
\end{tabular}

The data are presented as mean \pm S. E. M.

Figures in parentheses show $95 \%$ confidence limit of $\mathrm{LD}_{50}$ values.

Table 5. Hematological findings in each genotype of rats at ten weeks of age

\begin{tabular}{|c|c|c|c|c|c|c|c|c|c|}
\hline Sex & Symbol & $\begin{array}{c}\mathrm{RBC} \\
\left(\times 10^{6} / \mathrm{cmm}\right)\end{array}$ & $\begin{array}{c}\mathrm{Hb} \\
(\mathrm{g} / \mathrm{dl})\end{array}$ & $\begin{array}{l}\mathrm{Ht} \\
(\%)\end{array}$ & $\begin{array}{l}\mathrm{MCH} \\
(\mathrm{pg})\end{array}$ & $\begin{array}{l}\mathrm{MCV} \\
\left(\mu^{3}\right)\end{array}$ & $\begin{array}{c}\text { MCHC } \\
(\%)\end{array}$ & $\begin{array}{c}\mathrm{Th} \\
\left(\times 10^{4} / \mathrm{cmm}\right)\end{array}$ & $\begin{array}{c}\text { WBC } \\
\left(\times 10^{3} / \mathrm{cmm}\right)\end{array}$ \\
\hline \multirow[t]{7}{*}{ Female } & LEW & $8.55 \pm 0.13$ & $16.3 \pm 0.08$ & $47.3 \pm 0.21$ & $18.9 \pm 0.38$ & $55.5 \pm 0.69$ & $34.5 \pm 0.19$ & $64.6 \pm 1.45$ & $7.8 \pm 0.37$ \\
\hline & WM & $7.69 \pm 0.05$ & $16.0 \pm 0.05$ & $45.0 \pm 0.21$ & $20.9 \pm 0.11$ & $58.5 \pm 0.34$ & $35.7 \pm 0.13$ & $64.2 \pm 0.82$ & $3.2 \pm 0.13$ \\
\hline & F 344 & $8.00 \pm 0.03$ & $16.5 \pm 0.09$ & $46.8 \pm 0.42$ & $20.6 \pm 0.08$ & $58.6 \pm 0.43$ & $35.2 \pm 0.17$ & $78.0 \pm 3.02$ & $6.1 \pm 0.36$ \\
\hline & DRY & $7.08 \pm 0.08$ & $13.7 \pm 0.33$ & $41.2 \pm 0.61$ & $19.3 \pm 0.34$ & $58.2 \pm 0.43$ & $33.1 \pm 0.36$ & $63.7 \pm 1.14$ & $7.9 \pm 0.38$ \\
\hline & $\mathrm{LWF}_{1}$ & $7.82 \pm 0.05$ & $16.3 \pm 0.10$ & $45.8 \pm 0.25$ & $20.9 \pm 0.06$ & $58.6 \pm 0.17$ & $35.6 \pm 0.13$ & $69.5 \pm 0.89$ & $5.1 \pm 0.27$ \\
\hline & $\mathrm{FDF}_{1}$ & $7.43 \pm 0.07$ & $15.7 \pm 0.10$ & $44.1 \pm 0.28$ & $21.1 \pm 0.08$ & $59.4 \pm 0.27$ & $35.5 \pm 0.11$ & $84.5 \pm 1.02$ & $7.3 \pm 0.30$ \\
\hline & LWFD & $8.00 \pm 0.09$ & $16.2 \pm 0.15$ & $46.5 \pm 0.34$ & $20.3 \pm 0.10$ & $58.2 \pm 0.33$ & $34.9 \pm 0.14$ & $73.6 \pm 1.27$ & $6.6 \pm 0.34$ \\
\hline \multirow[t]{7}{*}{ Male } & LEW & $8.44 \pm 0.1$ & $16.4 \pm 0$. & $47.8 \pm 0$ & $19.5 \pm 0.21$ & $56.8 \pm 0$ & $34.3 \pm 0.26$ & $63.8 \pm 0.61$ & $8.9 \pm 0.24$ \\
\hline & W M & $7.76 \pm 0.05$ & $16.3 \pm 0.11$ & $47.3 \pm 0.30$ & $21.1 \pm 0.11$ & $61.0 \pm 0.19$ & $34.6 \pm 0.15$ & $67.1 \pm 1.41$ & $5.1 \pm 0.24$ \\
\hline & F 344 & $8.13 \pm 0.04$ & $16.5 \pm 0.09$ & $48.2 \pm 0.33$ & $20.3 \pm 0.06$ & $59.3 \pm 0.25$ & $34.2 \pm 0.15$ & $81.6 \pm 0.88$ & $7.3 \pm 0.27$ \\
\hline & DRY & $7.64 \pm 0.04$ & $14.7 \pm 0.19$ & $45.0 \pm 0.40$ & $19.2 \pm 0.29$ & $58.9 \pm 0.39$ & $32.7 \pm 0.38$ & $63.8 \pm 2.21$ & $9.9 \pm 0.48$ \\
\hline & $\mathrm{LWF}_{1}$ & $8.01 \pm 0.06$ & $16.7 \pm 0.15$ & $48.2 \pm 0.53$ & $20.9 \pm 0.11$ & $60.2 \pm 0.44$ & $34.7 \pm 0.12$ & $67.9 \pm 1.07$ & $6.8 \pm 0.31$ \\
\hline & $\mathrm{FDF}_{1}$ & $7.73 \pm 0.05$ & $15.9 \pm 0.09$ & $46.2 \pm 0.29$ & $20.5 \pm 0.10$ & $59.7 \pm 0.27$ & $34.4 \pm 0.11$ & $84.8 \pm 1.06$ & $7.9 \pm 0.22$ \\
\hline & LWFD & $8.09 \pm 0.11$ & $16.3 \pm 0.10$ & $48.0 \pm 0.33$ & $20.2 \pm 0.18$ & $59.4 \pm 0.55$ & $33.9 \pm 0.08$ & $77.6 \pm 3.24$ & $8.9 \pm 0.59$ \\
\hline
\end{tabular}

The data are presented as mean \pm S. E. M. for each group of ten animals.

い值は雌では LEW, 雄ではF344であった。各 $F_{1}$ 交 雑群の $\mathrm{LD}_{50}$ 值は雌雄とも 4 系統の值の範囲内にあり, 交雑群間の変異は系統間のそれよりも小さかった。また 各 4 元交雑群の $\mathrm{LD}_{50}$ 值も $\mathrm{F}_{1}$ と同様にほぼ 4 系統の值 の範囲内にあり, 変異も同程度であった。

4 系統と LWF 1 および $\mathrm{FDF}_{1}$ ならびにこれらを交雑 して得られた LWFD の雌雄の10週龄におけける血液・臨 床生化学検査值を Tables 5, 6 に示す。その結果,
LWFD はいずれの検査項目ともその起源となった 4 系 統や $\mathrm{F}_{1}$ 交雑群の值の範囲内にあり, 特に分散の大きい 項目は認められなかった。

\section{考察}

これまで実験動物の育成や遺伝的統御は単純化・均一 性を追求したものであった。これに対して近年では遺伝 
Table 6. Clinico-biochemical findings in each genotype of rats at ten weeks of age

\begin{tabular}{|c|c|c|c|c|c|c|c|c|c|}
\hline Sex & Symbol & $\begin{array}{c}\text { T. bil } \\
(\mathrm{mg} / \mathrm{dl})\end{array}$ & $\begin{array}{l}\text { T. chol } \\
(\mathrm{mg} / \mathrm{dl})\end{array}$ & $\begin{array}{l}\text { T. prot } \\
(\mathrm{g} / \mathrm{dl})\end{array}$ & $\begin{array}{c}\text { Alb } \\
(\mathrm{g} / \mathrm{dl})\end{array}$ & $\begin{array}{c}\text { BUN } \\
(\mathrm{mg} / \mathrm{dl})\end{array}$ & $\begin{array}{c}\text { GPT } \\
(\mathrm{K}-\mathrm{U})\end{array}$ & $\begin{array}{c}\text { GOT } \\
(\mathrm{K}-\mathrm{U})\end{array}$ & $\begin{array}{c}\text { Alp } \\
(\mathrm{KA}-\mathrm{U})\end{array}$ \\
\hline \multirow[t]{7}{*}{ Female } & LEW & $0.13 \pm 0.01$ & $87.4 \pm 1.53$ & $5.22 \pm 0.11$ & $2.39 \pm 0.05$ & $18.8 \pm 0.58$ & $13.9 \pm 0.68$ & $61.9 \pm 2.32$ & $32.2 \pm 2.45$ \\
\hline & W M & $0.11 \pm 0.01$ & $70.1 \pm 0.97$ & $5.22 \pm 0.03$ & $2.33 \pm 0.02$ & $16.3 \pm 0.36$ & $15.1 \pm 0.40$ & $66.3 \pm 1.65$ & $21.0 \pm 0.73$ \\
\hline & F 344 & $0.10 \pm 0.01$ & $72.2 \pm 2.28$ & $5.42 \pm 0.04$ & $2.59 \pm 0.02$ & $17.4 \pm 0.32$ & $13.1 \pm 0.55$ & $69.2 \pm 3.82$ & $64.0 \pm 2.11$ \\
\hline & DRY & $0.13 \pm 0.01$ & $95.4 \pm 4.29$ & $5.96 \pm 0.05$ & $2.66 \pm 0.03$ & $23.8 \pm 0.55$ & $15.7 \pm 0.52$ & $90.3 \pm 4.89$ & $24.0 \pm 1.16$ \\
\hline & $\mathrm{LWF}_{1}$ & $0.11 \pm 0.01$ & $76.0 \pm 0.99$ & $5.28 \pm 0.05$ & $2.37 \pm 0.03$ & $16.5 \pm 0.23$ & $13.7 \pm 0.73$ & $58.0 \pm 1.93$ & $25.0 \pm 1.32$ \\
\hline & $\mathrm{FDF}_{1}$ & $0.09 \pm 0.01$ & $74.2 \pm 1.42$ & $5.42 \pm 0.05$ & $2.47 \pm 0.02$ & $18.7 \pm 0.31$ & $16.7 \pm 0.67$ & $67.7 \pm 0.92$ & $31.2 \pm 0.82$ \\
\hline & LWFD & $0.10 \pm 0.01$ & $83.9 \pm 4.32$ & $5.39 \pm 0.07$ & $2.50 \pm 0.03$ & $18.7 \pm 0.58$ & $15.1 \pm 0.57$ & $63.4 \pm 4.48$ & $26.6 \pm 2.01$ \\
\hline \multirow[t]{7}{*}{ Male } & LEW & $0.14 \pm 0.01$ & $83.7 \pm 0.98$ & $4.61 \pm 0.05$ & $1.94 \pm 0.03$ & $18.5 \pm 0.30$ & $14.1 \pm 0.84$ & $71.4 \pm 4.07$ & $42.6 \pm 0.87$ \\
\hline & W M & $0.10 \pm 0.01$ & $56.1 \pm 0.77$ & $4.98 \pm 0.04$ & $2.22 \pm 0.02$ & $19.0 \pm 0.37$ & $20.1 \pm 1.59$ & $74.0 \pm 3.00$ & $26.5 \pm 1.17$ \\
\hline & F 344 & $0.09 \pm 0.01$ & $62.4 \pm 0.92$ & $5.38 \pm 0.03$ & $2.57 \pm 0.02$ & $19.7 \pm 0.45$ & $18.4 \pm 0.90$ & $91.7 \pm 2.34$ & $83.7 \pm 1.88$ \\
\hline & DRY & $0.13 \pm 0.01$ & $81.0 \pm 7.78$ & $5.66 \pm 0.10$ & $2.48 \pm 0.06$ & $22.8 \pm 1.19$ & $19.1 \pm 0.66$ & $113.0 \pm 8.09$ & $33.2 \pm 1.38$ \\
\hline & $\mathrm{LWF}_{1}$ & $0.12 \pm 0.02$ & $69.3 \pm 0.94$ & $4.99 \pm 0.03$ & $2.15 \pm 0.02$ & $17.4 \pm 0.30$ & $16.6 \pm 0.45$ & $70.7 \pm 3.31$ & $36.0 \pm 1.18$ \\
\hline & $\mathrm{FDF}_{1}$ & $0.14 \pm 0.01$ & $65.6 \pm 1.84$ & $5.61 \pm 0.06$ & $2.52 \pm 0.03$ & $22.4 \pm 0.28$ & $19.2 \pm 0.68$ & $96.4 \pm 3.27$ & $43.3 \pm 0.97$ \\
\hline & LWFD & $0.11 \pm 0.01$ & $62.3 \pm 2.10$ & $5.21 \pm 0.07$ & $2.32 \pm 0.04$ & $20.7 \pm 0.58$ & $18.5 \pm 1.16$ & $100.2 \pm 9.89$ & $43.3 \pm 1.99$ \\
\hline
\end{tabular}

The data are presented as mean \pm S. E. M. for each group of ten animals.

的複合化を求めて congenic や recombinant 系が育成 されている。さらに従来広く使用されているクローズド コロニーは遺伝的背景が不明確であることから，これに 代るものとして遺伝的背景の明らかな交雑群の作出が考 えられるよらになってきた。そこで新しい検定用動物の 開発を目的に 4 系統ラット間の交雑群について繁殖効率 と特性について検討した。もちろん検定用動物の価值は 恒久性・共通性・大量生産の観点から論じられなければ ならない。

第 1 の遺伝的恒久性と共通性については，規定された 近交系の維持方法 $[2,12]$ に従って継代され，充分な遺 伝的モニタリング $[2,7]$ のなされている近交系を増殖 し, 交雑群生産の基礎集団として使用している限りは近 交系と同様に問題になることはないであろう。なお，今 回の実験で生産された LWFD の 4 週龄の平均体重に産 次間変動が見られたが,これは生産集団が小さいために 交尾時期に片寄りが生じて生産日の分布が一定でなかっ たことや哺育仔数の調整をしなかったなどによるもの で，大量生産になれば問題はないであろう。

第 2 の大量生産の問題については, 今回の交雑実験で 示されたように出産率, 産仔数, 離乳率ともに優れ, 繁 殖効率に非常なへテロシス効果を得ることができた。特 に LWFD の生産の場合, 雌は 6 週齢で生産可能とな り，7〜8産まで継続することがでさ，近交系よりも極 めて高い生産効率を得ることができた。なお，マウスや ラットの場合に系統間交雑を行ならと必ずしも繁殖効率
が上昇するとは言えない[6,18]。今回の系統間交雑実験 においても，繁殖効率は必ずしも両親となった系統より も優れているとは言えなかった。この原因は出産率の低 いことによるものであったが，この現象が系統間の遺伝 的差異により生じた性的隔離を反映しているかどらかは 不明である。しかしながら 4 元交雑群の生産に問題とな るほどのものではなかった。

これまで 4 元交雑群や 8 元交雑群は遺伝的変異が大き いことから選抜実験のための基礎集団として利用されて きたが，実験動物あるいは検定用動物としての生物学的 価値については充分に検討されていない。一般に楽物な ぞの検定においては，1系統のみを使用した場合には得 られる結果に片寄りが生ずる可能性があるので, 交雑群 のような遺伝的にへテロな集団を使用した方がよいよう に思われる。さらに楽物の有效性や毒性試験にこのよう な交雑群を使用して特殊な反応值が得られた場合, ある いは予期しないような結果が得られた場合には, 交雑群 生産に使用された 系統あるいは $\mathrm{F}_{1}$ 交雑群を使用してそ の原因を追求することも可能になるなどの有利な点があ る。なお, 遺伝的に均一な集団よりも交雑群のような遺 伝的へテロ集団の方がよりレの遺伝的状態を反映して いるであろら[4]，といら考え方もある。

4 元交雑群は遺伝的変異が非常に大きいために薬物な どに対する反応性や形質の変異について考剫しなければ ならない。今回のビタミン $\mathrm{B}_{1}$ 塩酸塩に対する感受性には マウスと同様に系統間でかなりの差が見られたが，これ 
はマウスで想像されたように各系統の遗伝子組成と発育 の差異によるものであろう[17]。4 元交雑群の場合, へ テロシスを反映して感受性は低くなるものと想像された が， いずれも近交系や $\mathrm{F}_{1}$ 交雑群の感受性の範囲内であ った。しかしながら、これはビタミン $\mathrm{B}_{1}$ 塩酸塩のみの結 果であって, 他の薬物についても同様の結果が得られる かどうか不明である。また, 血液・臨床生化学検査值に ついても，4元交雑群はすべての項目で近交系間の範囲 内にあり, 分散も大きくはなかった。

以上より 4 元交雑ラットは繁殖効率が高く大量生産が 可能で, 恒久性・共通性を満足させるものであり, 充分 に検定用動物として利用できる可能性が示された。しか しながら検討しなければならないいくつかの問題が残さ れている。第1亿どのような近交系間の交雑群にするか である。一般的にはできる限り起源の異なる系統の交雑 が望ましいと考学られるが，これは繁殖効率のみならず 生産された交雑群の特性などを考慮して検討しなければ ならない問題である。さらに今回の実験では 4 元交雑群 について検討したが, 遺伝的へテロ集団の作出といら意 味では 8 元交雑群についても検討する必要がある。第 2 にこのような交雑群は個々の遺伝子座の遺伝子頻度につ いてはそれほど問題とはならないが，遺伝子組成全体を 見た場合には非常に多くの遺伝子型を有するへテロ集団 となる。このため実験に使用するにあたっては群間の遺 伝的差異が実験結果に影響を与えないようにしなければ ならない。今回, ビタミン $\mathrm{B}_{1}$ 塩酸塩のよらな急性毒性試 験や血液・臨床生化学検查ではこのよらな抽出誤差は問 題とはならなかったが, 発癌性や慢性毒性試験のような 長期毒性試験の場合には問題となるかもしれない。よっ て再現性の問題を含めて, さらに検討の必要がある。第 3 にこのような遺伝的へテロ集団であるために生殖試験 や遺伝毒性のよらに世代を経る実験の場合には各遺伝子 の分離または固定を考剫しなければならない。

\section{要 約}

いくつかの近交系間の交雑群を薬物の有効性や毒性試 験などの検定用動物として利用する試みとして，LEW， WM, F344 ならびに DRY の 4 系統ラット間の交雑群 についてその生産効率に特性について調べた。4 系統間 の総当り交雑 (diallel cross) と $\mathrm{F}_{1}$ の交雑実験の繁殖 成績から 4 元交雑群を生産するための最も生産効率の優 れた系統の組合せは $(\mathrm{LEW} \times \mathrm{WM}) \mathrm{F}_{1} \times(\mathrm{F} 344 \times \mathrm{DRY})$ $\mathrm{F}_{1}$ であり，この組合せの経産実験の結果から生産効率
は 4 系統に比較して非常に優れていた。さらに 4 元交雑 群は遺伝的へテロ集団にもかかわらず，ビタミン $\mathrm{B}_{1}$ 塩酸 塩に対する感受性試験に打いて近交系や $F_{1}$ に比較して 特異的な反応も示さなかったし, 血液・臨床生化学検査 值の分散も大きくはなかった。今後さらに検討しなけれ ばならない問題が残されているが，4 元交雑群は検定用 動物として充分に利用できる可能性が示唆された。

稿を終るにあたり実験に御協力いただいた当研究所の斎藤有 司, 藤沢奉武の品君に心から感謝致します。

\section{文献}

[1] Dobzhansky, Th. (1952). Nature and origin of heterosis. In Heterosis, pp. 218-223, Gowen, J. W. (edit.), Iowa State College Press, Ames.

[2] Festing, M. F. W. (1979). Inbred Strains in Biomedical Research. Macmillan Press, London.

[3] Gibson, D. C., Adelman, R. C., and Finch, C. (1979). Development of the Rodent as a Model System of Aging. Department of Health, Education, and Welfare Publication No. (NIH) 79-161.

[4] Gibson, D. C. (1972). Development of the Rodent as a Model System of Aging. Department of Health, Education, and Welfare Publication No. (NIH) 72121.

[5] Green, E. L., and Meier, H. (1965). Use of laboratory animals for the analysis of genetic influences upon drug toxicity. Ann. New York Acad. Sci., 123, 295-304.

[6] Green, E. L. (1966). Breeding system. In Biology of the Laboratory Mouse, pp. 11-22, Green, E. L. (edit.), McGraw-Hill, New York, Toronto, Sydney, London.

[7] Hoffman, H. A. (1978). Genetic quality control of the laboratory mouse. In Origins of Inbred Mice, pp. 217-234, Morse III, H. C. (edit.), Academic Press, New York, San Francisco, London.

[ 8 ] Howie, J. B., and Helyer, B. J. (1963). Renal disease associated with positive lupus erythematosus tests in a cross-bred strain of mice. Nature, 197, 197.

[9] 近藤恭司 (1970). 実験動物の遣伝形質, 実験動物学総論, pp. 32-106, 田嶋嘉雄編, 朝倉書店, 東京.

[10] Litchfield, J. T., and Wilcoxon, F. (1949). A simplified method of evaluating dose-effect experiments. J. Pharmacol. Exp. Therap., 96, 99-113.

[11] Meier, H. (1963). Experimental Pharmacogenetics. Academic Press, New York, London.

[12] Meier, H., and Fuller, T. L. (1966). Responses to drugs. In Biology of the Laboratory Mouse, pp. 447-455, Green, E. L. (edit.), McGraw-Hill, New York, Toronto, Sydney, London.

[13］日本実験動物研究会, 系統に関する専門部会 (1973). 実 験動物の表示法について, 実験動物, 22, 37-43.

[14] Papaioannou, V. E., and Festing, M. F. W. (1980). Genetic drift in a stock of laboratory mice. Lab. Animals, 14, 11-13.

[15] Rice, M. C., and O'Brieh, S. J. (1980). Genetic 
variance of laboratory outbred Swiss mice. Nature. 283, 157-161.

[16] Shull, G. H. (1952). Beginnings of the heterosis concept. In Heterosis, pp. 14-48, Gowen, J. W. (edit.), Iowa State College Press, Ames.

[17] Tanase, H., Matsunuma, N., and Suzuki, Y. (1979). Effect of proximate environment on drug suscepti- bility of mice. Exp. Animals, 28, 507-518.

[18] Wakasugi, N., Tomita, T., and Kondo, K. (1967). Differences of fertility in reciprocal crosses between unbred strains of mice: DDK, KK and NC. $J$. Reprod. Fert., 13, 41-50.

[19] 山田淳三 (1980). クローズドコロニーの問題点につい て, 実験動物, 29, 465-473. 